\title{
Relationship between Perception of Village Cadre's Interpersonal Communication and Health Service Satisfaction
}

\author{
${ }^{* 1}$ Dede Yuliarti, ${ }^{2}$ Firman Parlindungan \\ *1Universitas Teuku Umar, Indonesia, dedekyuliarti@gmail.com \\ 2Universitas Teuku Umar, Indonesia, firman@utu.ac.id
}

Submitted: 20/09/2021

Revised: $28 / 10 / 2021$

Accepted: 22/11/2021

How to cite this article: Yuliarti, D. \& Parlindungan, F. (2021). Relationship between perception of village cadre's interpersonal communication and health service satisfaction. International Journal of Education, Language, and Religion, 3(2), 88-93. https://doi.org/10.35308/ijelr.v3i2.5058

\begin{abstract}
Interpersonal communication is communication that occurs between two or more people, which is usually not formally regulated. In interpersonal communication, each participant uses all elements of the communication process. Village cadres have a very important role in monitoring, controlling and paying attention to the health condition of the community in Keude Tanjong Village, XVI District, West Aceh Regency. The servicesprovided by village cadres with the community at the posyandu are positive and can be well received by visitors at the posyandu, so that the satisfaction achieved gets positive results. This research is quantitative. Respondents who became the target of the study were mothers or people who visited the posyandu in Keude Tanjong village. Data collection using the Likert scale method, in-depth interviews, and using SPSS (Statistical Product and Service Solutions) application access. Analysis of the services provided by village cadres to the community gota good response, but there were also some respondents who did not accept the services provided, so that when they got respondents it was not pleasant, it was marked by negative perceptions of the various characteristics of these things and the triggers of the problem. The results showed that the relationship between interpersonal communication of village cadres and satisfaction with health services at the posyandu between posyandu cadres and the community in Keude Tanjong Village was strongly positive, namely, the relationship between interpersonal communication of village cadres and satisfaction of health services in the same direction where the greater the interpersonal communication relationship of village cadres, it would be the greater the satisfaction of health services in the village of Keude Tanjong.
\end{abstract}

\section{Keywords}

interpersonal communication; village cadres; health service satisfaction

\section{Introduction}

Communication is a very important part of human life, because communication is the most important nteraction as social beings in this world. The origin of the word communication is a process of conveying the meaning of words from one existence/entity or group to another by using signs or symbols, sign language, and other communication processes that are easy to understand together. We have also started doing communication since we were born into the world, the use of communication 
that is conveyed is through crying. This means that we cannot be separated by communication (Evi Estel Hutagaol, 2012).

Interpersonal communication is defined by an expert in the field of communication, namely, Joseph A. Devito (2009) who is written in his book entitled "The Interpersonal Communication Book" which contains: "the process of sending and receiving messages between two persons, or among a small group of people. persons, with some effect and some immediate feedback", which means: "The process of sending and receiving messages between two people, or among a small group of people, with some effect and some immediate feedback." (2009:4). The aspects contained in interpersonal communication are defined in the opinion of Devito (2009), interpersonal communication can run effectively, if there are five aspects of communication effectiveness that can be fulfilled by the communicator. Interpersonal communication will be more effective if the conditions in communicating there are equality. That is, there must be an open acknowledgment that both have value and value, and both parties have something to agree on with one's behavior verbally and non-verbally on the other side (Suranto, 2011). Equality is where every individual can have the same and equal position without being discriminated against (Pangestu, 2011). According to him, the effectiveness of interpersonal communication is divided into five, namely: openness, empathy, support, positive attitude, and equality.

According to Tribowo (2013), interpersonal communication is the process of sending messages or opinions between the communicator (the sender of the message) and the communicant (the recipient of the message), with the effect of direct feedback so that we can find out whether there is a message given that has an impact. positive or negative. In this case, the interaction of social life is very important. This is determined by two main factors, namely, social contact and communication (Alven. 2008). Thus, this shows that interpersonal communication plays a very important role in every element of social relations between humans. The role of the communicator with the communicant can carry out their duties effectively, so that they can exchange ideas in the message conveyed to achieve behavior change between the two parties.

Interpersonal communication is communication that is related in terms of meeting face to face, influencing each other, listening to each other, conveying something with openness or nothing being covered up, and having sensitivity to someone's opinions and behavior with the feedback effectobtained directly (Whaid \& Indra 2021). Communication also includes in all things human activities, which are very inherent in every aspect of human life. Experts also provide detailed definitions related to this communication. Interpersonal communication is the interaction that occurs between the communicator (message giver) and the communicant (message recipient) which usually occurs formally or informally. (Adisasmito, 2007; Sampe, 2019). In this case, every participant involved must use all the elements of the communication process itself.

In everyday contexts, interpersonal communication is needed in many professions, one of which is village cadres. Village cadres or often referred to as Posyandu cadres are "key people" who organize and lead village people to move towards achieving common goals in improving community health status. Village cadres are actively involved in the social learning process carried out by all levels of the village community (Wahyuni, Sari, \& Fatimah, 2021).

In general, village cadres are tasked with growing and developing, as well as mobilizing initiatives, participation, and self-help mutual assistance (Permendes No. 3/2015, Article 18) who work in Community Health Centers (Puskesmas). Health centers or health workers that are easily accessible to 
even remote areas are Posyandu (Integrated Service Posts), because village cadres are always in contact with the community, the interpersonal communication skills of cadres greatly affect the success of their duties. Unfortunately, research on the interpersonal communication relationships of village cadres is very limited. Effective interpersonal communication is the basic capital for cadres in carrying out health promotion and carrying out their roles and duties as community drivers (Rohmani, 2020).

Therefore, this study aims to add to the literature on the relationship of interpersonal communication between village cadres and health service satisfaction. This research strengthens the study of communication, especially interpersonal communication in the context of health services. Specifically, this study will answer the research question whether statistically, the higher the interpersonal communication of village cadres, the higher the satisfaction of health services.

Interpersonal communication or a relationship between two people is more of a communication that is done directly or face to face, with the possibility that each participant can catch quickly the reactionsof others directly during the communication. As for communication in this sense, it is the process of sending messages/opinions between two people or a certain group with various kinds of effects or impacts (feedback) obtained, so the communication that takes place is very effective for both parties. In the definition, each component must be seen and explained as part of a unified whole (integrated) in the act of interpersonal communication that takes place. According to Ubaedy (2008: 13) interpersonal communication is communication that occurs directly between two people or a small group, where each of them has personal emotional involvement, commitment is needed in a relationship. To beclear, we often see the relationship between teachers to students, children to parents, husbands to wives, and lecturers to students.

\section{Method}

This research uses quantitative correlation research method. Quantitative method is research that uses data collection techniques to determine whether there is a relationship with the degree of relationship between several variables. Quantitative research methods are certainly related to variables that are assigned a value to be associated with the aim of getting the desired results. This method is also when the results have been obtained, the results are absolute or inviolable (Noor, 2011).

In the basic concepts of scientific research, we have often heard and know the term about variables. In quantitative research methods, it is no stranger to use the designation of these variables. The goal is to determine the compatibility between one variable and another variable in connecting something and given a numbered value. The relationship of several variables in the social context of the real world. Correlation research only questions the magnitude of the relationship between two variables. In this design there is no assessment between the independent variable and the dependent variable (Noor, 2011).

The research location as a target is the village of Keude Tanjong, Kaway XVI District, West Aceh District. The reason for choosing Keude Tanjong village according to the local community population is recorded as a stunting rate which is quite relevant and concerning. Not only that, the communication relationship between posyandu cadres and the community is at the heart of the problem, especially when posyandu activities are taking place. For this reason, the researchers also traced their relationship directly to each other. The population in Keude Tanjong village in 2016 data consisted of 220 men and 225 women. The research sample used a questionnaire system with 40 informants/respondents who visited the posyandu in the village of Keude Tanjong. The researcher conducted a questionnaire survey by visiting each house of the mother who was domiciled in the village of Keude Tanjong. Data collection 
using the Likert scale method, and using SPSS (Statistical Product and Service Solutions) application access. The data analysis concluded that the researcher sought to find out the interpersonal communication/interaction between posyandu cadres and the local community, with aspects of openness, empathy, support, and equality.

\section{Results}

The purpose of this study was to answer the question of whether there is a significant relationship between interpersonal communication of village cadres and satisfaction with health services. The results of the Pearson Correlation test show that statistically, there is a significant relationship between interpersonal communication of village cadres and satisfaction with health services. Table 1 below shows the results of the correlation test.

Table 1. Pearson Correlation test

\begin{tabular}{|c|c|c|c|}
\hline \multicolumn{3}{|c|}{$\begin{array}{c}\text { Interpersonal Communication } \\
\text { of Village Cadres }\end{array}$} & \multirow{2}{*}{$\begin{array}{l}\text { ealth Service } \\
\text { Satisfaction } \\
.678^{* *}\end{array}$} \\
\hline Interpersonal & Pearson Correlation & 1 & \\
\hline Communication of Village & Sig. (2-tailed) & & .001 \\
\hline Cadres & $\mathrm{N}$ & 20 & 20 \\
\hline \multirow{3}{*}{ Health Service Satisfaction } & Pearson Correlation & $.678^{* *}$ & 1 \\
\hline & Sig. (2-tailed) & .001 & \\
\hline & $\mathrm{N}$ & 20 & 20 \\
\hline
\end{tabular}

Based on the table above, it shows that the relationship between interpersonal communication of village cadres and satisfaction with health services at the posyandu between posyandu cadres and the community in Keude Tanjong Village is strongly positive, namely 0.678 , the relationship between interpersonal communication of village cadres and satisfaction of health services is in the same direction where the greater the interpersonal communication relationship of village cadres. , the greater the satisfaction with health services . From the comparison between the values of sig and, the results obtained are sig $=0.001$ $<=0.05$ so that the decision has a strong relationship between interpersonal communication of village cadres and satisfaction with health services in Posyandu between posyandu cadres and the community in Keude Tanjong Village.

In addition, the relationship between cadres and the community is also well established. Satisfaction obtained is also a pure result or not made up. So, there is no harm in this study having satisfactory results related to interpersonal relationships between the community and the community in Keude Tanjong.

According to Tribowo (2013), interpersonal communication is a process of sending messages or opinions between communicators and communicants, with the effect of direct feedback to find out whether any messages given have a positive or negative impact. In the role of interpersonal communication, the interaction of social life is very important. This is determined by two main factors, namely, social contact and communication (Alven. 2008). Thus, this shows that interpersonal communication plays a very important role in every element of social relations between humans. The role of the communicator with the communicant can carry out their duties effectively, so that they can exchange ideas in the message conveyed to achieve behavior change between the two parties.

\section{Discussion}

\section{Interpersonal Communication between Community and Village Cadres}


During the research, the researcher asked several questions that had been prepared regarding the respondents' expectations on how to communicate with the people of Keude Tanjong village with posyandu cadres in the local village. Attitudes highlighted by respondents are positive, such as polite, understanding and very open. People who visited the posyandu in Keude Tanjong village stated that they really needed the role of cadres and had good and effective interpersonal communication interactions, so that between the two there was no sense of sophistication or shyness and so on. As for some of the respondents' opinions regarding behavior in communicating at the posyandu, namely there are times when the cadres are cold to posyandu visitors, such as angry, indifferent, indifferent, not having a sense of responsibility and so on which makes the visitors feel uncomfortable. However, not all community responses are of bad value to cadres, from the results of the study that researchers conclude that there are some people who understand the characteristics of cadres or they understand the behavior situation of cadres.

\section{Conclusion}

Based on the above results indicate that the interpersonal relationship between the community and cadres is very strong. The comparisons that resulted from the 2 types of questionnaires that were made also obtained satisfactory results. However, not all of the public's responses were like what was stated that the community still did not accept the services provided by the cadres, because there were those who disagreed, contradicted each other and had different perceptions. The problem is that people are dissatisfied with the services provided by the cadres. In addition, the relationship between cadres and the community is also well established. Satisfaction obtained is also a pure result or not made up. So, there is no harm in this study having satisfactory results related to interpersonal relationships between the community and the community in Keude Tanjong.

For this reason, improving the quality of interpersonal communication interactions between cadres and the community in Keude Tanjong village is positive or very good. The interactions are very closely related, because both parties need each other, including on the part of the community who really need the role of cadres in the context of paying attention to the health condition of the families of the Keude Tanjong village community.

The suggestion that the researchers can convey is that village cadres are expected to always use good language to the community, very close, open, and sympathetic relationships or interactions are the main keys in providing services to the community, so as to create effective interpersonal communication relationships between village cadres and local community.

\section{References}

Adisasmito., (2007). Health system. Jakarta: King Grafindo Perkasa.

Alven. (2008). Interpersonal Communication at Posyandu. Jakarta: Interaction of Health Promotion Information and Reference Magazines.

Arianto, D. N. (2015). The effect of organizational communication and compensation on employee morale. Journal of Economia, 11(2), 177-185.

Devito. Joseph. A (2009). The Interpersonal Communication Book. USA: Pearson Education.inc

Hutagaol, E.E., Agustin, Helfi. (2012)., Interpersonal Communication of Health Officers in Posyandu Activities in the Work Area of the Muara Siberut Health Center, Mentawai Regency., Jakarta: Research Article.

Noor. J. Dr., (2011). Research methods. Jakarta: Kencana Prenamedia Group

Pangestu, F. R. (2021). The communication strategy of the "colorful mighty" program on Radio

Perkasa FM Tulungagung. SOURCE: Journal of Communication Studies, 7(2), 104-114.

Permendes No. 3/2015, Article 18) Regulation of the Minister of Villages, Development of 
Disadvantaged Regions, and Transmigration of Village Facilitators

Rohmani, N. (2020). Community Empowerment through Effective Communication Training for Posyandu Cadres. Yogyakarta: Journal of Community Service

Sarinah, \& Aziz. A (2010). Relationship between Interpersonal Communication and Commitment to Organization with Job Satisfaction of PT. Perkebunan Nusantara III (Persero). Yogyakarta: Analytic Journal

Sampe, N. (2019). Hacking the interpersonal communication skills of Christian families entering the 4.0 era. Journal of Contextual Christian Theology and Education, 2(1), 72-82.

Satrianegara, (2014). Relationship of Interpersonal Communication with BPJS Patient Satisfaction in the Internal Nurse Room of Makassar City Hospital, Makassar: Scientific Journal of Health Diagnosis Volume, 2302-2531.

Suranto. (2011). The effect of effective communication to improve student learning outcomes. Scientific Journal of Education, XI(1), 13-24.

Tribowo, (2013), Health Center and Hospital Services. Jakarta: Salemba Medika Ubaedy (2008), Interpersonal Communication, Literature Review: Media Library (13).

Wahid, D., \& Indra, U. (2021). Literature review: Digital political communication Anies Baswedan. Journal of Interaction, 5(2), 228-239.

Wahyuni., Sari, N. W., \& Fatimah, F. (2021). Literature study of factors related to visits to Posyandu under five in Indonesia. Journal of Endurance, 6(2), 360-372.

Wardani, N. I., Martanti, L. E., \& Wahyudi, T. (2019). The effect of education with linzi media on the attitudes and performance of cadres in monitoring the nutritional status of children under five. Journal of Midwifery, 9(1), 24-29.

Wandiro. J.A. (2016). Communication Pattern of Posyandu Officers in Improving the Health of the Elderly Community. eJournal of Communication Studies, 2016, 4 (4): 85-97 ISSN 2502-597X, ejournal.ilkom.fisip-unmul.ac.id 